\title{
Soft Tissue Sarcoma of the Head and Neck Pathologic Primary Tumor TNM Finding v8
}

National Cancer Institute

\section{Source}

National Cancer Institute. Soft Tissue Sarcoma of the Head and Neck Pathologic

Primary Tumor TNM Finding v8. NCI Thesaurus. Code C136663.

A pathologic finding about one or more characteristics of soft tissue sarcoma of the head and neck, following the rules of the TNM AJCC v8 classification system as they pertain to staging of the primary tumor. 